\title{
Edible Fungi Consumed by the Lamba and Bemba People of Haut-Katanga (DR Congo)
}

\author{
Bill Kasongo Wa Ngoy Kashiki, André De Kesel, Ernest Kabange Mukala, \\ Koen Bostoen, and Jérôme Degreef
}

\section{ABSTRACT}

The objective of this work is to establish a list of species of edible fungi consumed by the Lamba and Bemba people of Haut-Katanga (DR Congo). This study contributes to the valorization of edible fungi gathered in the miombo woodlands of Haut-Katanga. A survey was conducted among Lamba and Bemba people of the peri-urban area of Lubumbashi. The first author conducted structured and semi-structured surveys among 331 people, mostly women aged 30-50.

The results show the existence of thirty-eight edible species belonging to 9 genera and 8 families. The majority is ectomycorrhizal (66\%) followed by Termitomyces $(\mathbf{2 1 \%})$, while only a few are saprotrophic (13\%). Lamba and Bemba people consume all taxa. Twenty-three local names have been recorded in their respective languages, i.e., Kilamba and Kibemba, two closely related Bantu languages belonging to the family's Eastern clade. The Lamba and Bemba do not consume species of the genera Russula (Russulaceae) and Boletus (Boletaceae). We succeeded in reconstructing the conceptualization underlying the creation of several Kibemba and Kilamba mushroom names. Popular and scientific taxonomies rarely overlap: one and the same species may have different names in Kilamba and Kibemba, while one and the same name in Kilamba and/or Kibemba is often used for several congeneric species. Species considered toxic and not consumed do not have a Kilamba or Kibemba name of their own. Instead, they are collectively referred to by a term fyana fya bene, literally meaning "big (dangerous) children of them" and signaling that local consumers reject those species.

Keywords: Ethnomycology, edible fungi, Miombo Woodlands, HautKatanga, Lamba, Bemba.

\section{INTRODUCTION}

The consumption of edible fungi by humans is ancient [1]. Archaeological records reveal the dietary use of edible fungi by Chilean people 13,000 years ago [2]. Edible fungi were gathered from forests in ancient Greek and Roman times and were highly valued, although more highly valued by highranking people than by peasants [3].

The present-day consumption of edible fungi is also well documented in several parts of Africa [4]-[14].

In Tanzania, during the rainy season, the Bena, Hehe, Makua, Nyamwezi, Nyiha and Samba people eat edible fungi every day [15]. The Bakoya hunter-gatherers of Mekambo (Ogooué-Ivindo) in Gabon consume almost their entire harvest [8]. In Cameroon, it has been shown that the average annual individual consumption is $1.1 \mathrm{~kg}$ fresh weight for the Bagyeli hunter-gatherers and $1.4 \mathrm{~kg}$ for their agriculturalist neighbors [16]. Nikuze et al. [17] show a self-consumption of $9 \%$ of the total harvest in southwestern Burundi.

In the vicinity of three major mining towns (Lubumbashi, Likasi and Kolwezi) in Katanga (DR. Congo), Parent and
Submitted : April 21, 2021

Published : May 17, 2021

ISSN: $2684-1827$

DOI: $10.24018 /$ ejfood.2021.3.3.289

Bill Kasongo Wa Ngoy Kashiki* Université de Lubumbashi, Faculté des Sciences Agronomiques, Ecology, Restoration Ecology and Landscape, 2 Route Kasapa, 1825 Lubumbashi, D. R. Congo.

(e-mail: billkasongo@ gmail.com) André De Kesel

Meise Botanic Garden, Nieuwelaan 38, B1860 Meise, Belgium.

Ernest Kabange Mukala

Université de Lubumbashi, Faculté des Lettres et Sciences Humaines, 2 Route Kasapa, 1825 Lubumbashi, D. R. Congo. Koen Bostoen

UGent Centre for Bantu Studies, Department of Languages and Cultures, Ghent University, Belgium.

Jérôme Degreef

Fédération Wallonie-Bruxelles, Service Général de l'Enseignement supérieur et de la Recherche Scientifique, Rue A. Lavallée 1, B-1080 Bruxelles, Belgium.

*Corresponding Author
Thoen [18] estimated the annual harvest of edible fungi to reach 20 tons. They also estimated that the consumption of villagers from that area fluctuates around $30 \mathrm{~kg}$ per person per year. Considering edible fungi are available throughout the entire rainy season (17 weeks), villagers living close to the forests consume approximately $2 \mathrm{~kg}$ per person per week, i.e., between 200 and 300 grams per day. Edible fungi are increasingly considered by rural African people as a substitute for meat, fish and vegetables and contribute to food security in times of crisis [18]-[21].

Some species of edible fungi are consumed because of their high mineral and vitamin content [22]-[24], while others are consumed for their medicinal virtues [25]-[27].

The miombo woodlands of Haut-Katanga (DR Congo) are home to an important diversity of edible fungi [5]. During the rainy season, large quantities of edible fungi are collected and sometimes sold along roads and in urban markets. The abundance and consumption of edible fungi in this sub-region is documented thanks to pioneering work by De Kesel et al. [5], Malaisse [28] and Parent and Thoen [18]. Nonetheless, reliable data on the endogenous knowledge of Katangese 
people remains fragmentary. Knowing the local names of edible fungi is a good indication of their use, especially as food. The present study is meant to help the process of valuation of edible fungi from the miombo woodlands of Haut-Katanga by presenting a list of consumed species with their scientific name, corresponding local name(s) as well as reference specimens.

\section{MATERIALS AND METHODS}

The present study was carried out in the peri-urban area of the city of Lubumbashi, Province of Haut - Katanga, in the southeastern part of the DR Congo.

The collection of ethnomycological data was carried out between December 2014 and April 2015. Three villages were selected: Tumbwe (11. 47244 S - 27.38669 E), Mususwa (11.51682 S - 27.62456 E) and Baya (11.87492 S - 27.45975 E).

The choice of these villages was motivated by their proximity to the miombo woodlands. In those villages we found speakers of Kilamba and Kibemba, who share the same endogenous knowledge of mushrooms. A total of 331 villagers were sampled. 211 of them identified themselves as first-language speakers of Kilamba and 120 of Kibemba. The local names presented in Table 1 below are subdivided according to the first language of the interviewees. In line with the fact that Kilamba and Kibemba speakers closely cohabit in the villages targeted, many mushroom names overlap in the two languages, some minor phonological differences notwithstanding. The work consisted of structured and semi-structured surveys using freshly collected fruitbodies. A simple and short questionnaire developed by De Kesel et al. [10] was used for the interviews. The questions were asked both in Kiswahili, the region's main language of communication and in the local languages with the assistance of a local translator. Sixty-seven percent of the surveyed people were women between 30 and 50 years. The validation of local names was based on the reproducibility of the same questions on several people. Only information confirmed by minimum $3 / 4$ of the respondents has been considered. The fresh fruitbodies were presented to the respondents. Reference specimens were collected and dried with a mushroom field dryer [8]. Voucher specimens are numbered Kasongo 58 to Kasongo 95 and kept at the Herbarium of the Faculty of Agricultural Sciences at the University of Lubumbashi (DR Congo).

\section{RESULTS}

\section{A. Diversity of Edible Fungi Consumed by Lamba and Bemba People}

Thirty-eight species (ectomycorrhizal 66\%, Termitomyces $21 \%$ and saprotrophic 13\%) distributed in 9 genera and 8 families (Cantharellaceae 46\%, Lyophyllaceae 20\%, Russulaceae 15\%, Agaricaceae 5\%, Amanitaceae 5\%, Auriculariaceae 3\%, Polyporaceae 3\% and Schizophyllaceae $3 \%$ ) were recorded (Fig. 1). The local names in Kilamba and/or Kibemba are presented in Table I.

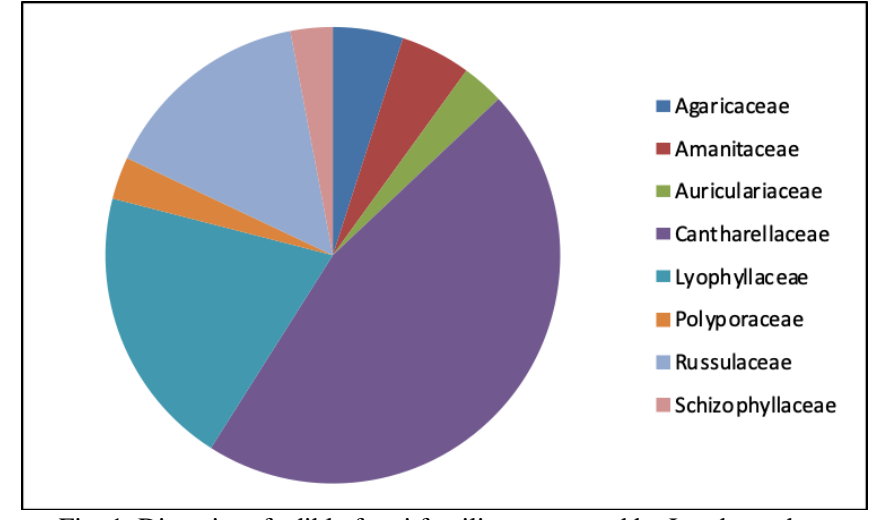

Fig. 1. Diversity of edible fungi families consumed by Lamba and Bemba people.

\section{DISCUSSION}

\section{A. Diversity of Fungi Consumed by Lamba and Bemba People}

Results presented in Fig. 1 and Table I confirm the knowledge of edible fungi among the Lamba and Bemba people of Haut-Katanga. This vernacular knowledge is reflected in the attribution of a name in Kibemba and/or Kilamba to the species consumed. We collected thirty-eight species corresponding to 23 different names in the two languages. The work of Härkönen et al. [6] among the Lamba people in Zambia has shown the consumption of Amanita aff. annulatovaginata, Amanita flammeola, Amanita crassiconus, Amanita tanzanica, Mycoamaranthus congolensis, Russula compressa and the rejection of Lactifluus gymnocarpoides, Macrolepiota dolichaula and Termitomyces medius.

Compared to the richness of edible macromycetes evaluated at about 100 species in the Katangese miombo woodlands [5], edible fungi are underused in the Lubumbashi region. These results support and complement the pioneering works of Degreef [11], Malaisse [28] and De Kesel et al. [5] who listed 39, 47 and 87 species of edible fungi in HautKatanga, respectively.

In addition, several authors have mentioned the rejection of some species by local populations. Boni \& Yorou [29] reported 24 species consumed by the Bariba people compared to 21 species consumed by the Gando people and 18 species for the Yom people out of a total of 38 species inventoried in the N'dali region of Benin. On the other hand, the Fon and Holli people of the same country eat 7 and 9 species respectively out of a total of 12 edible species [30]. Härkönen et al. [6] found 10 to 12 species consumed in Zambia. The Bena, Hehe, Makonde, Nyamwezi, Sumbwa, Sukuma and Yao people in Tanzania consume 20-28 species of edible fungi [15]. The Bofi people of the Lobaye in the Central African Republic consume 20 species of edible fungi [31]. Finally, 4 species out of 31 are picked and consumed near the Mare aux Hippopotames in the Bala reserve in Burkina Faso [32]. 
TABLE I: LOCAL NAMES OF EDIBLE FUNGI CONSUMED By LAMBA AND BEMBA PEOPLE

\begin{tabular}{|c|c|c|c|}
\hline Scientific names & Voucher Specimens & Local names in Kilamba & Local names in Kibemba \\
\hline Amanita aff. Rubescens Pers. & BK80 & rubosa & lubosa \\
\hline Amanita loosii Beeli & BK72 & ntente, nteria, nderema & ntente, ntelia, ndelema \\
\hline Auricularia cornea Bull. & BK85 & kungwa & kungwa \\
\hline Cantharellus microcibarius Heinem. & BK60 & katiretire, butondo & katiletile, butondo \\
\hline Cantharellus addaiensis Henn. & BK67 & katiretire, butondo & katiletile, butondo \\
\hline $\begin{array}{c}\text { Cantharellus afrocibarius Buyck \& V. } \\
\text { Hofst. }\end{array}$ & BK73 & bwitondwe, butondo & bwitondwe, butondo \\
\hline Cantharellus congolensis Beeli & BK86 & winnyata & winnyata \\
\hline $\begin{array}{l}\text { Cantharellus defibulatus (Heinem.) } \\
\text { Eyssart. \& Buyck }\end{array}$ & BK82 & bwitondwe, butondo & bwitondwe, butondo \\
\hline Cantharellus densifolius Heinem & BK71 & bwitondwe, butondo & bwitondwe, butondo \\
\hline $\begin{array}{c}\text { Cantharellus gracilis Buyck \& V. } \\
\text { Hofst. }\end{array}$ & BK76 & bwitondwe, butondo & bwitondwe, butondo \\
\hline $\begin{array}{c}\text { Cantharellus humidicola } \text { Buyck \& V. } \\
\text { Hofst. }\end{array}$ & BK64 & butondo & butondo \\
\hline $\begin{array}{c}\text { Cantharellus mikemboensis De Kesel } \\
\text { \& Degreef }\end{array}$ & BK74 & bwitondwe, butondo & bwitondwe, butondo \\
\hline $\begin{array}{l}\text { Cantharellus miomboensis Buyck \& } \\
\text { V. Hofst. }\end{array}$ & BK81 & bwitondwe, butondo & bwitondwe, butondo \\
\hline Cantharellus platyphyllus Heinemann & BK75 & bwitondwe, butondo & bwitondwe, butondo \\
\hline $\begin{array}{l}\text { Cantharellus pseudomiomboensis } \\
\text { Buyck \& V. Hofst. }\end{array}$ & BK83 & bwitondwe, butondo & bwitondwe, butondo \\
\hline Cantharellus ruber Heinem. & BK87 & katiretire, bwitondwe & katiletile, bwitondwe \\
\hline Cantharellus splendens Buyck & BK92 & bwitondwe, butondo & bwitondwe, butondo \\
\hline Cantharellus stramineus De Kesel & BK79 & bwitondwe, butondo & bwitondwe, butondo \\
\hline $\begin{array}{l}\text { Cantharellus subcyanoxanthus } \\
\text { Buyck, Randrianj. \& Eyssart }\end{array}$ & BK77 & bwitondwe, butondo & bwitondwe, butondo \\
\hline Cantharellus symoensii Heinem. & BK90 & bwitondwe, butondo & bwitondwe, butondo \\
\hline Lactarius kabansus Peger \& Piearce & BK68 & kabansa & kabansa \\
\hline $\begin{array}{c}\text { Lactarius tenellus Verbeken \& } \\
\text { Walleyn }\end{array}$ & BK70 & kabansa & kabansa \\
\hline $\begin{array}{c}\text { Lactifluus edulis (Verbeken \& Buyck) } \\
\text { Buyck }\end{array}$ & BK84 & musefwe, busefwe & musefwe, busefwe \\
\hline $\begin{array}{c}\text { Lactifluus gymnocarpoides } \\
\text { (Verbeken) Verbeken }\end{array}$ & BK91 & musefwe & musefwe \\
\hline $\begin{array}{c}\text { Lactifluus gymnocarpus (R.Heim ex } \\
\text { Singer) Verbeken }\end{array}$ & BK95 & pampe & pampe \\
\hline $\begin{array}{c}\text { Lactifluus rubroviolascens (R. Heim) } \\
\text { Verbeken }\end{array}$ & BK89 & pampé & pampé \\
\hline Lentinus squarrosulus Mont. & BK93 & kimpekeshi & kimpekeshi \\
\hline $\begin{array}{c}\text { Macrolepiota africana (Heim) } \\
\text { Heinem. }\end{array}$ & BK78 & kishiki bowa, kariwa na mukombo & kishiki bowa, kaliwa na mukombo \\
\hline $\begin{array}{c}\text { Macrolepiota dolichaula (Berk. \& } \\
\text { Broome) Pegler \& R. W. Rayner }\end{array}$ & BK94 & kishiki bowa, kariwa na mukombo & kishiki bowa, laliwa na mukombo \\
\hline Schizophyllum commune Fr. & BK88 & busepa & busepa \\
\hline $\begin{array}{c}\text { Termitomyces aurantiacus (R. Heim) } \\
\text { R. Heim }\end{array}$ & BK59 & karara mputa & kalalala mputa \\
\hline Termitomyces clypeatus Heim & BK62 & butumbwe & butumbwe \\
\hline Termitomyces letestui (Pat.) R. Heim & BK58 & katoto & katoto \\
\hline $\begin{array}{c}\text { Termitomyces medius R. Heim \& } \\
\text { Grassé }\end{array}$ & BK63 & karara mputa & kalala mputa \\
\hline $\begin{array}{c}\text { Termitomyces microcarpus (Berk. \& } \\
\text { Br.) Heim }\end{array}$ & BK61 & $\begin{array}{l}\text {,kasensera, tumena sarera, } \\
\text { kasanwa }\end{array}$ & tumena salela, kasangwa \\
\hline $\begin{array}{c}\text { Termitomyces reticulatus Van der } \\
\text { Westh. \& Eicker }\end{array}$ & BK66 & karara mputa & kalala mputa \\
\hline Termitomyces striatus (Beeli) Heim & BK69 & karara триtи & kalala mputa \\
\hline $\begin{array}{c}\text { Termitomyces titanicus Pegler \& } \\
\text { Piearce }\end{array}$ & BK65 & bukungwa, kikungwa & kikungwa \\
\hline
\end{tabular}


Lowy's [33] study highlights the tendency to consume edible fungi more rarely when populations move away from forest ecosystems. On the other hand, rural communities bordering forest massifs maintain and even acquire a suspicious attitude towards edible fungi [34].

It is important to point out that certain genera, although containing edible species appreciated elsewhere, are rejected in the Lubumbashi region. The most typical case is that of the genera Russula and Boletus. It is very likely that boletes are rejected because of their tube hymenophore [35]. These results corroborate those of Härkönen et al. [36] showed the rejection of these species respectively in some areas of Tanzania and in the southern part of Cameroon. Nevertheless, Phlebopus sudanicus is prized by the Bobo people of Burkina Faso [21]. Afroboletus luteolus, Boletus loosii, Phlebopus silvaticus, $P$. purpereus, Rubinoboletus balloui, $R$. luteopurpureus, $R$. phlebopoides are consumed in eastern Burundi [37]. Kelly et al. [38] also report the consumption of Boletus edulis by the Gbagyi people of Nigeria.

The local names of the edible fungi consumed in the Lubumbashi region often refer to the shape, color, smell, and taste of the fruitbody. They also draw inspiration from the habitat, resemblance to an animal and certain distinctive or important properties for local people. These results are consistent with the literature [7], [31], [39], [40], [41]. The naming of different species of fungi by a collective name (homonyms) demonstrates, in some cases, under specification in folk taxonomy as compared to scientific nomenclature.

Some vernacular names deserve additional comments.

Katoto is the diminutive of mutoto "navel" and thus means "small navel" ([42], p. 256, where it is also reported as a kind of edible mushroom). This name highlights the prominent nipple of Termitomyces letestui. This pictorial term allows one to quickly recall the habitus of this voluminous species.

Schizophyllum commune is called busepa. This noun is derived from a verb stem closely linked with the gathering of wild food, i.e., sepa meaning "to pull out", "to sort, pick out, select" ([42], p. 677), "pick, gather, collect wild fruit, roots, etc.; eat in bush, famine time; forage" [43]. This mushroom is extracted from dead wood.

Chanterelles are called bwitondwe and butondo, which means "eaten to satiation", cf. lya butondo butondo "to eat slowly" ([42], p. 63). The White Father's Bemba-English dictionary provides citondo as a kind of edible mushroom ([42], p. 136), which probably designates a single item, while butondo is the collective noun.

Termitomyces titanicus is called kikungwa meaning "big" or "giant", which refers to its gigantic size. This noun is possibly also deverbative, i.e., derived from the verb stem kungwa, which is the passive form of kunga meaning "to be plentiful, abundant, thick, yield abundantly" among other things ([42], p. 289).

Kabansa refers to Lactarius kabansus and is derived from lubansa meaning "plot, courtyard". These are gregarious mushrooms that prefer open habitats (bare ground) comparable to a well-cleared plot. The place where this edible mushroom grows is also known as mubansa (pl. mibansa); its plural is bakabansa and its diminutive kababansa ([42], p. 208, 442).
Cantharellus congolensis is called winnyata, which literally means "do not trample on me" because of its black coating and the fact it also is an edible fungus. In Kibemba and Kilamba, the verb stem for "stamp on, trample upon, walk on" is nyanta ([42], p. 567; [43], p. 112) with a prenasalized second consonant, i.e., nt. In Kiswahili, this prenasalization got lost leading to the corresponding verb stem nyata, which is observed in this mushroom term.

It should be noted that one and the same species sometimes has several local names in one and the same language, depending on its characteristics and growth stage. Amanita loosii is designated with three names referring to its three different characteristics. The first one is ndelema from lelema "glow", "be pretty" ([42], p. 318). It is a mushroom with a shiny cap. Ntelia means slimy mushroom and ntente from the verb tenteka 'place on top'. It is a mushroom that wears a cap straight on its stipe like a soldier. Filume fya ntelia and filume fya ndelema refer to Amanita pudica and literally means "the males of Amanita loosii". In Kibemba, cilume, the singular of filume, refers to the "male of any animal" ([42], p. 104). Being considered the male of Amanita loosii, it is rejected from the list of locally consumed species.

Gregarious edible fungi are often designated by a plural name, which is also the case of tumena salela/sarera (plural of kamena salela/sarera), the local name of Termitomyces microcarpus.

Most vernacular names have only local usage, but the use of some of them sometimes extends over large geographical areas. In Haut-Katanga and neighboring Zambia, edible fungi are referred to as bowa in Kibemba (see also [42], p. 38) and uwowa (amowa) in Kilamba (see also [43], p. 79). All edible fungi are called ubwoba in Burundi [41], bowa in Malawi [44]; mbowa, ubuaba or uhwa in Zambia [45], uboyoga in certain languages of Tanzania [46] or boua in Central African Republic [31]. The noun roots reconstructed as *jòbà/jògà and usually preceded by the noun prefix $(u) b u$ - are common generic terms for edible mushrooms across the Bantu language family [47]. It dates back as far as Proto-Bantu, the most recent common ancestor of all Bantu languages spoken some 4000 to 5000 years ago in their putative homeland in the borderland between present-day Cameroon and Nigeria [48]; which points towards the antiquity of edible fungi consumption in Bantu-speaking Africa.

Species considered toxic and consumed in the Lubumbashi region are designated by a collective name, i.e., fyana fya bene literally meaning "the big children of them/these". The noun fyana is the plural of cana "big child, youngster", which is itself the augmentative of mwana "child". In Bantu languages, augmentative and diminutive classes often have affective values, more specifically "small is beautiful" and "big is ugly and dangerous" ([49], p. 191). This depreciative value of the augmentative ties in with the fact that it is used in Kibemba and Kilamba to designate mushrooms seen as being "toxic", "harmful", or "poisonous". These results corroborate those of Härkönen et al. [6] who found a collective designation of all fungi considered toxic in Zambia and Mozambique. In addition, the Nagot and Holli people of Benin call ohunto edjo all inedible fungi, which means "bad edible fungi" [30]. Note that apart from the prefix $(b) u$-, also found in the generic nouns bowa and uwowa, many edible mushroom names in Kibemba and Kilamba start with the 
prefix $k a-$, commonly used in Bantu languages to form diminutives, which tend to have an appreciative connotation [49], p. 191).

\section{CONCLUSION}

The main objective of this work was to establish a list of species of edible fungi consumed by the Lamba and Bemba people of Haut-Katanga (DR Congo). This work contributes to the valorization of edible fungi produced in the miombo woodlands of this region.

Thirty-eight edible species distributed in 9 genera and 8 families corresponding to 23 local names were reported by the local Lamba and Bemba people. Each species consumed has a local name. A species may have two or more local names in the same language, or several species of the same genus may be designated by a single local name. The local Kilamba and Kibemba names given to the edible fungi are often meaningful, as many of them are semantically transparent in the sense that their meaning highlights a specific feature of the mushroom in question. All species considered toxic are designated by a depreciative collective name meaning "big (dangerous) children of them". Species of the genera Russula (Russulaceae) and Boletus (Boletaceae) are not consumed.

\section{ACKNOWLEDGEMENTS}

B. Kasongo, A. De Kesel \& J. Degreef acknowledge ASBL MIKEMBO (Lubumbashi, RD Congo) and BAK (Biodiversité au Katanga, DR Congo) for financial and logistic support of our fieldwork in Katanga (2012-2015). B. Kasongo acknowledges the GTI (Global Taxonomy Initiative, Belgium) for the logistic and financial support of three working visits to Belgium (2014-2016).

\section{REFERENCES}

[1] Aaronson 2000. Fungi. In K.F. Kiple \& K.C. Ornelas, eds. The Cambridge world history of food, pp 313-336. Cambridge, UK, Cambridge University Press. 1958 pp.

[2] Rojas, C. Mansur, E. 1995. Ecuador: informaciones generales sobre productos non madereros en Ecuador. In Memoria, consulta de expertos sobre productos forestales no madereros para America Latina y el Caribe. Serie Forestal \#1. Santiago, Chile, FAO Regional Office for Latin America and the Caribbean. pp. 208-223.

[3] Buller, A.H.R. 1914a. The fungus lores of the Greeks and Romans. Transactions of the British Mycological Society, 5: 21-66.

[4] Milenge, K. and De Kesel, A. 2020. Wild edible ectomycorrhizal fungi: an underutilized food resource from the rainforests of Tshopo province (Democratic Republic of the Congo). Journal of Ethnobiology and Ethnomedicine. 1-13 p.

[5] De Kesel, A., Kasongo, B., Degreef, J. 2017. Champignons comestibles du Haut-Katanga, (R.D. Congo) AbcTaxa. 17: 1-290.

[6] Härkönen, M., Niemelä, T., Mbindo, K., Kotiranta, H., Piearce, G., 2015. Zambian mushrooms and mycology. Norrlinia 29:1-208p.

[7] Yorou, N.S., De Kesel, A. 2002. Connaissances ethnomycologiques des peuples Nagot du centre du Bénin (Afrique de l'Ouest). Proceeding of XVI the AETFAT Congress, Brussels 2000. Systematics and Geography of Plants 71: 627-637.

[8] Eyi NDong, H., Degreef, J., De Kesel, A. 2011. Champignons comestibles des forêts denses d'Afrique centrale, Taxonomie et identification. ABC Taxa Vol 10. 6-17 p.

[9] Boa, E.R. 2006. Champignons comestibles sauvages : vue d'ensemble sur leurs utilisations et leur importance pour les populations. Produits forestiers non ligneux 17. FAO, Rome. 157

[10] De Kesel, A., Codjia J.T.C., Yorou S.N. 2002. Guide des champignons comestibles du Bénin. National Botanic Garden of Belgium, Brussels $135 \mathrm{p}+35 \mathrm{p}$.

[11] Degreef, J., Malaisse, F., Ramnmelo, J., Baudart, E. 1997. Edible mushrooms of the zambezian woodland area. A nutritional and ecological approach. Biotechnol. Agron. Soc. Environ. 1(3): 221-231.

[12] Buyck, B., Nzigidahera, B. 1995. Ethnomycological notes from Western Burindi- Belg. Journ. Bot. 128 (2): 131-138.

[13] Morris, B. 1994. Bowa: Ethnomycological notes on the macrofungi of Malawi. In J.H. Seyani \& A.C. Chikuni (eds). Proceedings of the XIIIth Plenary meeting of AETFAT, Vol. 1: 635-647. Zomba, Malawi, 2-11 April 1991. Zomba, Malawi, National Herbarium and Botanic Gardens of Malawi.

[14] Piearce, G.D. 1985. Livingstone and fungi in tropical Africa. Bulletin of the British Mycological Society, 19(1): 39-50.

[15] Härkönen, M., Niemelä, T., Mwasumbi, L., 2003. Tanzanian mushrooms. Edible, harmful and other fungi, Norrlinea 10. Helsinki, Botanical Museum, Finnish Museum of Natural History. 200 p.

[16] Dijk, H. V., Onguene, N. A., Kuyper, T. W. 2003. Knowledge and Utilization of Edible Mushrooms by Local Populations of the Rain Forest of South Cameroon. Ambio Vol. 32: 19-23p.

[17] Nikuze, N. Nzigidahera, B. \& Degreef, J. 2020. Analyse socioéconomique de la filière des champignons sauvages comestibles des forêts claires de Rumonge (Sud-Ouest du Burundi). Tropicultura. Vol. 38 (2): 1-23.

[18] Parent, G., Thoen, D. 1977. Food value of edible mushrooms from upper. Shaba Region. Economic Botany, 31 (4): 436-445.

[19] Idu, M., Osemwegie, O., Timothy, O., Onyibe, H.I. 2007. A survey of plants used in traditional healthcare by Waja tribe Bauchi State, Nigeria. Plant Archives 7(2): 535-538p.

[20] Akpaja, E.O., Okhuoya J.A., Eliwer Heferere, B.A. 2005. Ethnomycology and indigenous uses of mushrooms among the Binispeaking people of Nigeria: A case study of Aihuobabekun community near Benin City, Nigeria. International Journal of Medicinal Mushroom 7(3): 373-374.

[21] Guissou, K.L.M., Sankara, P., Guinko, S. 2005. Phlebopus sudanicus, ou la viande des Bobos, un champignon comestible dans le Département de Satiri au Burkina Faso. Cryptogamie Mycologie 3 195-203p.

[22] Ogundana, S.K., Fagada, O.E. 1982. Nutritive value of some Nigerian mushrooms. Food Chemistry 8:263-268.

[23] Adewusi, S. R. A., Alofe, F. V., Odeyemi, O., Afolabi O.A., OKE, O.L. 1993. Studies on some edible wild mushrooms from Nigeria: Nutritional, teratogenic and toxic considerations. Pl. Foods Human Nutr. 43: 115-121.

[24] Aletor, V.A. 1995. Compositional studies on edible tropical species of mushrooms. Food Chemistry 54:265-268.

[25] Adjanohoun, E.J. 1995. La biodiversité tropicale face au développement des industries pharmaceutiques. Pharm. Méd. trad. afr. Pp 3-18.

[26] Wang, Y.C. 1987. Mycology in ancient China. Mycologist, 1: 59-61p

[27] Thoen, D., Parent, G., Lukungu, T., 1973. L'usage des champignons dans le Haut-Shaba (République du Zaïre). "Problèmes sociaux Zaïrois". Bulletin du CEPSE. 100-101:69-85pp.

[28] Malaisse, F. 1997. Se nourrir en forêt claire Africaine. Approche écologique et nutritionnelle. Presses Agronomiques de Gembloux. P. 15-35.

[29] Boni, S., Yorou S.N. 2015. Diversité inter-ethniques dans la consommation de champignons sauvages de la région de N'dali au Bénin. Tropicultura. 33,4: 266-276pp.

[30] Codjia, J.E.I., Yorou, N.S. 2014. Ethnicity and gender variability in the diversity of Wild Useful Fungi in Pobe region, Benin. Journal of Applied Biosciences 78:6729-6742

[31] Malaisse, F., De Kesel, A., N'Gasse, G., Lognay, G. 2008. Diversité des champignons consommés par les pygnées Bofi de la Loboye en République Centrafricaine. Geo-Eco-Trop 28:1-11.

[32] Guissou, K.M.L., Sankara, P., Guinko, S. 2002. Les champignons macroscopiques de la Réserve de la Mare aux Hippopotames de Bala: Diversité et étude ethnomycologique. Études sur la Flore et la Végétation du Burkina Faso et des Pays Avoisinants 7: 45-48p.

[33] Lowy, B. 1974. Amanita muscaria and the Thunderbolt legend in Guatemala and Mexico. Mycologia, 66: 189-191.

[34] Lowore, J., Boa, E. 2001. Bowa markets: local practices and indigenous knowledge of wild edible fungi. Egham, UK, CABI Bioscience.

[35] Kamou, H., Nadjombe, P., Guelly, K. A., Yorou, S. N., Maba, L. D. Akpagana, K. 2015. Les Champignons sauvages comestibles du Parc National Fazao-Malfakassa (PNFM) au Togo (Afrique de l'Ouest) Diversité et connaissances ethnomycologiques. Agronomie Africaine 27 (1): $37-46$.

[36] Härkönen, M., Saarimäki, T., Mwasumbi, L. 1994b. Tanzanian mushrooms and their uses. 4. Some reddish edible and poisonous 
Amanita species. Karstenia, 34: 47-60p.

[37] Degreef, J., Kasongo, B., Niyongabo E., De Kesel, A. 2020. Edible mushrooms, a vulnerable ecosystem service from African miombo woodlands. Biotechnol. Agron. Soc. Environ. 2020 24, 70-80.

[38] Kelly, A. U., Abubakar, S., Ebele, O.O., Archibong, V. E., Chidozie, O. P. 2015. Ethnomycology: Edible and Medicinal Mushrooms of the Indigenous Gbagyi People of Nigeria. Int.J.Curr.Biotechnol., 2015, 3(3):1-7.

[39] Koni Muluwa, J., Eyi Ndong, H. C., Degreef J., Koen, B. A. G. 2013. Champignons consommés par les Pygmées du Gabon: analyse linguistique des myconymes baka et kóya. Africana Linguistica. 19: 109-135.

[40] Roulon-Doko, P. 1998. Chasse, cueillette et cultures chez les Gbaya de Centrafrique. Paris, L'harmattan: 540 pp.

[41] Buyck, B. 1994. Ubwoba : les champignons comestibles de l'Ouest du Burundi. Bruxelles, AGCD. 123pp.

[42] Anonymous. 1954. The White Fathers' Bemba-English Dictionary London: Longmans, Green \& Co. for the Northern Rhodesia \& Nyasaland Joint Publications Bureau.

[43] Doke, C.M. 1933. English-Lamba vocabulary. Johannesburg: Witwatersrand University Press.

[44] Morris, B. 1984. Macrofungi of Malawi: some ethnobotanical notes. Bull. British. Mycol. Soc. 18: 48-57.

[45] Pegler, D.N., Piearce, G.D. 1980. The edible mushrooms of Zambian. Kew Bull. 35: 475-491.

[46] Härkönen et al. 1995. Edible mushrooms of Tanzania. Karstenia.35: 191.

[47] Bastin, Yvonne, André Coupez, Evariste Mumba \& Thilo C. Schadeberg (eds.). 2002. Bantu Lexical Reconstructions 3. Tervuren: Royal Museum for Central Africa, online database:https://www.africamuseum.be/nl/research/discover/human_s ciences/culture_society/blr (last accessed May 7, 2021).

[48] Bostoen, K. 2020. The Bantu Expansion: Some Facts and Fiction. In M. Crevels \& P. Muysken (eds.), Language dispersal, diversification, and contact, 227-239. Oxford: Oxford University Press.

[49] Schadeberg, T. Bostoen, K. 2019. Word Formation. In M. Van de Velde, K. Bostoen, D. Nurse \& G. Philippson (eds.), The Bantu Languages (Second Edition), 172-203. New York: Routledge. 